See discussions, stats, and author profiles for this publication at: https://www.researchgate.net/publication/333152585

\title{
Adoption of Library Management System: Motivation and Challenges in Developing Countries
}

Conference Paper · March 2019

DOI: 10.1109/INFOMAN.2019.8714659

CITATIONS

6 authors, including:

Ayooluwa Aregbesola

Landmark University

22 PUBLICATIONS 43 CITATIONS

SEE PROFILE

Jerome Idiegbeyan-ose

19. Covenant University Ota Ogun State, Nigeria

49 PUBLICATIONS 73 CITATIONS

SEE PROFILE
READS

371

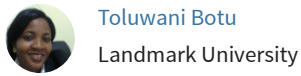

15 PUBLICATIONS 10 CITATIONS

SEE PROFILE

Owolabi Sola Emmanue

Landmark University

25 PUBLICATIONS 22 CITATIONS

SEE PROFILE

Some of the authors of this publication are also working on these related projects:

LF-ViT: Development of a Virtual Reality Guided Tour Mobile App of Landmark University Teaching and Research Farm View project

Examination of the Nexus Between Academic Libraries and Accreditation: Lessons from View project 


\section{Adoption of Library Management System: Motivation and Challenges in Developing Countries}

\author{
Ayooluwa Aregbesola $^{1}$, Toluwani Eyiolorunshe ${ }^{2}$, \\ Jerome Idiegbeyan-ose ${ }^{3}$, Sola Owolabi ${ }^{5}$, Foluke \\ Okocha $^{6}$ \\ Centre for Learning Resources \\ Landmark University \\ Omu-Aran, Nigeria \\ e-mail: aregbesola.ayooluwa@lmu.edu.ng
}

\author{
Felicia Yusuf $^{4}$ \\ Centre for Learning Resources, \\ Covenant University, \\ Ota, Nigeria \\ e-mail: felicia.yusuf@covenantuniversity.edu.ng
}

\begin{abstract}
The purpose of this paper was to discuss adoption of library management system, motivation and challenges in developing countries. It started with the introduction of the concept, it further discussed the trend in the adoption of library management system in the developing countries. The paper also highlighted the factors influencing the adoption of library management system in developing countries, it also discussed the motivating factors in adopting library management system to library services. The paper further pointed out the challenges in adopting LMS in developing countries, such as prolonged adverse economic conditions, limitations in budgetary provision, infrastructural and political challenges facing these countries as well as inadequate technical-know required for the deployment and usage of modern working tools and technologies involved within LMS. Based on these, the paper concluded and recommended that there should be adequate planning, preparation and consultations before embarking on the adoption of a software for LMS, regular training and retraining should be conducted for library personnel on the use of the software, institutional support and the reputation of the company that developed the software should also be considered among others.
\end{abstract}

Keywords-Library Management System; Information and Communication Technology; Library and Information Centres; Developing Countries.

\section{INTRODUCTION}

The pervasiveness of information and communication technologies (ICTs) in every aspect of educational institutions system in developing countries, library users' increasing demands for flexible scholarly and learning environments, more utilization of the Internet and other electronic resources for learning activities, and the need for unhindered/round-the-clock access to information for satisfying their information needs [1] pressurise libraries to meet these demands which have resulted in automating library processes, and services. These brought about the need for library management system.

Library management system is a specialized type of software systems and web-based technologies that integrate functionality for creating, developing, managing, storing, providing access to, and preserving library resources or collections. These systems are used for acquisition, cataloguing, indexing, storage, management, preservation, and delivery of library resources and services [2].

Library management system is not a sudden event but an evolving phenomenon which started with an attempt to automate some of the library services in order to solve the problem of monotony associated with it. Library Automation was first used in 1936 by D.S. Harder and was referred to as "the computerization or mechanization of all library activities" [3]. Automation as defined by Dictionary of Information and Library Management is "the use of machines to do work with very little supervision." [4] referred to it as "the application of information technologies to library operations and services with little supervision by people."

From the 1930s to late 1970 s the use of computers in the library was limited and was predominant in the libraries of developed countries such as Britain and the America. As observed by [5] it was only the largest libraries in the world such as the Library of Congress and the British Library who had substantial databases of catalogue records. Within this period as well, some university libraries had integrated computerization into some of their activities but could only be visible within the confinement of their institutions, lack of internet at that time made it impossible for libraries to share their data outside of the libraries. However, starting from mid 1980s down to late 1990s, the use of computers had spread across all fields of human endeavours. Personal computers have replaced desktops, internet was already in place and catalogues of some libraries could be accessed from the internet, other innovations were also coming on board. The 1990s was a period that initiated the growth of the internet and the evolution of digital libraries [6].

In view of the perceived benefits of LMSs in libraries, the current study examines the factors that influence its adoption, motivations and challenges encounter in adopting LMS in developing countries.

\section{TREND IN THE ADOPTION OF LIBRARY MANAGEMENT SYSTEM IN THE DEVELOPING COUNTRIES}

Developing countries have some common attributes which range from poor health facilities, inadequate 
infrastructures, high level of poverty among the citizens, low level of education to corruption at all levels of governance. These attributes contribute to the slow pace involved in the adoption of LMS in these countries. Adoption of LMS therefore is still an ongoing project in most of these countries. For instance, in Sub-Sahara Africa and in particular Nigeria, computerization of some library activities came on board as early as 1948 at the University of Ibadan with the introduction of microform technology and the purchase of three microform readers [7] which later metamorphous to establishment of UI Computing Centre. However, this was not sustained due to poor maintenance and lack of trained personnel to man it, this was the case in many other African countries.

Apart from international organisations which were heavily founded by their parent's body such as International Institute of Tropical Agriculture (IITA) which was said to have been the first success story of full automation in Africa by 1984 . Due to lack of infrastructures many academic and public libraries in Africa depended solely on donor funding. As noted by [5], Makerere University Library in Uganda, benefited from donor funding through the African Virtual University Library Initiative of the World Bank to equip the library with computers and installed Internet connectivity.

The current trend in the adoption of LMS in developing countries shows that the awareness, acceptance and the implementation of LMS is on the increase. [6] observed some rapid changes in the attitude of universities in sub Saharan Africa in that many of them have embarked on integrating information and communication technology in their work settings in such areas as digitisation and preservation of content. Further innovation is tending towards the digitization of their intellectual outputs. Some University libraries especially private universities in Nigeria have started implementing institutional repositories to capture and preserve the intellectual output such as theses, working papers, technical reports, seminar papers, etc. produced by their students and faculties [6].

The cost of implementing these technologies has always been the major challenge, however, many libraries across the globe are migrating from proprietary source and now tending towards the adoption of Open Source Systems. It is believed that open source software is cost effective and flexible. The definition given by Open Source Initiative summarises the essence of its wider acceptability "Open source promotes software reliability and quality by supporting independent peer review and rapid evolution of source code. To be certified as open source, the license of a program must guarantee the right to read, redistribute, modify, and use it freely".

\section{FACTORS INFLUENCING THE ADOPTION OF LMS IN DEVELOPING COUNTRIES}

Library environment and workflow has greatly been influenced positively, due to the automation of its processes and services. The importance of this cannot be overemphasized as the herculean routine task of library staff are highly simplified and efficient particularly when relevant technologies/systems are deployed appropriately. Before libraries can take the full advantage of the benefits that come with automation such as job satisfaction and productivity, certain parameters must be put in place and therefore influence the adoption of LMS particularly in developing countries. These include adequate planning, preparation and consultations before adopting LMS. Others are adequate funding, uninterrupted power supply and required ICT infrastructures.

Careful selection of the software that will cater for the library's visions and goals is paramount. The library must validate the reliability of the software/system to be adopted from other libraries using it. It is also important to consider institutional support and the reputation of the company that developed the software/technologies. Provision for regular training and retraining of both staff and library users must be in place.

Most of the professional librarians in almost all libraries in Nigeria were trained in traditional librarianship which makes it difficult for them to cope with the technological requirements to deploy LMS. Hence, staff training and reskilling is required for successful deployment of LMS. This is extremely important in the management of eresources, development and deployment of e-services, data management, troubleshooting when the system malfunctions [8].

These will invariably avert some impending challenges that could be encountered in the process of implementing LMS in a library which can lead to dissatisfaction of library staff and reduce productivity in turn.

\section{MOTIVATIONS FOR ADOPTING LIBRARY MANAGEMENT SYSTEM TO LIBRARY SERVICES}

The library as an integral and significant part of educational system has undergone phenomenal development in the use of ICTs which have substantial influence in the process of information resources' acquisition, processing, storage and use in developing countries. Consequently, libraries are required to provide access to huge information resources in diverse format such as print (books, Journals) and electronic format (e-books, e-journals/journal articles, CD-ROMs, Internet resources/services) as well as bibliographical information about these resources have influenced the adoption of LMS.

Similarly, libraries as a fundamentally service oriented units, where services are rendered to people with diverse information needs, (who are also from different) backgrounds, cultures, emotions, skills and behaviours, are bound to meet these various information needs of its patrons in the easiest, most efficient, and most comprehensive way possible [9] Therefore, there is need for highly efficient technologies/systems and processing tools in order to deliver these services promptly and also accomplish the quest to meet and support the information needs of library users.

Traditionally, libraries have two main divisions. They are the Technical Services and Readers Services. The most compelling reason for the adoption LMS in the Technical services division of a library is to make the catalog available to users remotely over the local area network and the [10] 
Another relevant justification is to avoid the unnecessary duplication that takes place when the same title is cataloged repetitively [11]. Automation permit the use of integrated bibliographic records which saves time during cataloging of materials as well as ensuring uniformity of cataloguing procedures.

Academic libraries are tending towards acquisitions of more of electronic resources than print/physical resources. Reference [7] observed that on the resource side, print material and physical items are no longer dominant collections; electronic resources are fast outpacing physical materials to become the dominant library resources, especially in the academic libraries. Automation helps to alleviate the repetitive tasks peculiar to library which in turn saves time. Automating library processes and services using an integrated web-based library management system has really compressed the load of routine tasks performed by library staff. The integration of library activities/services eliminates duplication of data and waste of effort which leads to high and increasing efficiency of operation in the library.

In the Readers' Services section routine tasks include registration of users, book reservation, charging and discharging of library materials, inter-library loan services, current awareness service, etc. The tasks in the library are generally tedious, monotonous and time consuming which may weaken the satisfaction of staff thereby making them less productive. For instance, computers are being used as excellent research assistants; they can help users find materials that would not have been discovered on the shelves. In the traditional academic library, huge efforts have been channeled to make library materials accessible through subject, title, and author entries via printed catalogues. However, in an automated library environment, library software can provide library users with even greater access by allowing them to search annotation, summary, and other bibliographical details of the materials they are searching for.

Library Management Software makes it possible to search by any bibliographical information such as author's name, keywords, illustrations, etc. which is limited within traditional system. In addition, library users of varied backgrounds find computer/online searching interesting and quick. With Online Public Access Catalogues (OPAC), the library holdings are available to all users even at their convenient zones (such as residence and offices).

Therefore, the increasing expectation of users, changes in library usage patterns brought about by, increasing use of information and communication technologies, information seeking strategy - including preference for online searching more sophistication in the new interfaces of knowledge delivery has resulted in automating library processes, and services which underscore the adoption of library management system. Library automation which implies the application of information technologies to library operations and services with little supervision by people in developing countries is limited and have been mainly adopted in the academic libraries.

\section{CHALLENGES Hindering THE ADOPTION OF LMS IN DEVELOPING COUNTRIES}

The first application of computer technologies in libraries was in the 1950s in the United States. This is followed by Britain and other European countries. However, technology in Nigerian libraries was first deployed with the introduction of microform technology at the University of Ibadan in 1948 [12]. Reference [13] also reported that between the mid1970s and late 1980s several attempts were made by the foremost universities in Nigeria such as University of Ibadan, Ibadan; University of Lagos, Akoka; University of Nigeria, Nsukka; Ahmadu Bello University, Zaria, to automate the library services but, they all failed due to lack of adequate system analysis before carrying out the project. Until recently, only private universities could boast of functionary library automation, and this was made possible because of adequate funding by the owners of the universities.

A substantial number of libraries in the developed world have automated virtually all their services, however only few libraries in developing countries particularly in Nigeria have fully taken the huge benefits of adopting library management systems. This is not unconnected to prolonged adverse economic conditions, limitations in budgetary provision, infrastructural and political challenges facing these countries as well as inadequate technical-know required for the deployment and usage of modern working tools and technologies involved within LMS. Other factors include high cost of ICT equipment, lack of ICT strategies and policies, frequent Power Outages and poor maintenance culture $[14,15,16,17]$.

Reference [18] opined that the successful deployment of technology in the university library is greatly influenced by the quality of manpower to implement the process and use the technology. Relevant and continuous information technology (IT) training is inevitably required to maximise the benefit of adopting LMS. The ever-changing library environment and workflow in the information age has mandated library staff to acquire ICT skills in order to enjoy all the benefits of library automation. This new environment in the academic library is not without some shortcomings. Lack of proper planning before adopting LMS is a problem that has led to other problems including job dissatisfaction of library staff. Reference [13], emphasising the importance of planning stated that planning must precede successful development of an automated library management system. Libraries planning to automate their processes and services must state clearly what problems are being currently encountered; how would automation reduce or eliminate the problems; and what is the aim of automating the library. A lot of planning is required because of cost implication of the project in terms of equipment and staff/ user training.

Reference [19] observed that the cost effect of acquiring the hardware for the automation used to be expensive, and still relatively expensive for developing countries and this has been one of the problems of adopting LMS. There is also the problem of power supply and library staff adapting to the new systems/technologies. All these could constitute a much more complexity than a pre-automation situation where 
everything was done manually. Success of automation in any library depends largely on the ability of staff to facilitate and implement the process. Therefore proper, frequent, and regular in-house IT training is a necessity if the maximum benefit is to be gained from the adoption of LMS [18].

\section{CONCLUSION AND RECOMMENDATIONS}

The current trend in the adoption of LMS in developing countries shows that the awareness, acceptance and the implementation of LMS is on the increase. Some libraries have even gone further to embarked on integrating information and communication technology in their work settings in such areas as digitisation and preservation of content. Further innovation in these libraries is tending towards the digitization of their intellectual outputs. Some have started implementing institutional repositories (IRs) to capture and preserve the intellectual output such as theses, working papers, technical reports, seminar papers, etc. produced by their students and faculties [6]. However, the cost of implementation is still a major factor in these countries. Due to the inherent characteristics of the developing countries, many libraries who have adopted LMS could not maintain and sustain it, hence they are now embracing Open Source Software as alternative to the proprietary. In order for libraries in the developing countries to meet up with their counterparts in the developed countries:

It is therefore recommended that:

1. There should be adequate planning, preparation and consultations before embarking on the adoption of a software for LMS

2. There should be regular training and retraining for library personnel on the use of the software.

3 . The library must validate the reliability of the software to be adopted from other libraries using it.

4. It is also important also to consider institutional support and the reputation of the company that developed the software.

\section{REFERENCES}

[1] Thanuskodi, S. (2011). Usage of electronic resources at Dr TPM Library, Madurai Kamaraj University: a case study. DESIDOC Journal of Library \& Information Technology, 31(6), 437-445.

[2] Tramboo, S., Shafi, S.M., Gul, S., 2012. A study on the open source digital library softwares: special reference to DSpace, EPrints and Greenstone. International Journal of Computer Applications, 59 (16), $1-9$.

[3] Aina, L. O., Mutula, S. M. \& Tiamiyu, M.A. (Eds). (2008). Information and knowledge management in the digital age: concepts, technologies and African perspectives. Ibadan, Third world information services limited.

[4] Aregbesola, A. \& Eyiolorunshe, T. (2018). Job satisfaction, productivity and automation of academic libraries in Nigeria. In R. A.
Egunjobi \& J.A. Akerele (Eds.), Library automation: The Nigerian experience (pp. 106-122). Nigeria, First Festschrift Publications.

[5] Hopkinson, A. (2009). Library automation in developing countries: the last 25 years, Innovation Development, 25(4), pp. 304-12.

[6] Mutula, S. M. (2012). Library automation in sub Saharan Africa: case study of the University of Botswana. Program: Electronic Library, 46(3), pp.292-307, https://doi.org/10.1108/00330331211244832 Permanent link to this document: https://doi.org/10.1108/00330331211244832

[7] Rosenberg, D. (2006). Towards the digital library in Africa. The electronic library, 24(3), 289-293.

[8] Nkhoma-Mawumza, A. G. (2003). Library Automation: The Role and Significance of Library Automation Plans. Huria: Journal of the Open University of Tanzania, 5(2003), 120-33.

[9] Simonton, W. (1969). Automation of cataloguing procedures. Library automation: A state of the art review, 44.

[10] Haravu, L.J. (2004), Library Automation: Design, Principles and Practice, Allied Publishers, New Delhi.

[11] Wang, Y. \& Dawes, T. A. (2012). The next generation integrated library systems: A promise fulfilled. Information and Libraries, 76-85.

[12] Speirs, M. (2010). The development of Information and Communication Technologies in Nigerian Libraries. http://eprints.rclis.org/14464/2/The Development of Information an d_Communication_Technologies_in_Nigerian_Librariesreformatted_ single_spaced.pdf. Accessed July 5, 2017.

[13] Aina, L. O. (2004). Library and Information science text for Africa Ibadan, Third world information services limited.

[14] Idiegbeyan-ose, J, Nkiko, C, Idahosa,M \&Nwokocha, N. (2016). Digital Divide: Issues and Strategies for Intervention in Nigerian Libraries, Journal of Cases on Information Technology 18, (3) pp. 2939. DOI: $10.4018 /$ JCIT.2016070103

[15] Idiegbeyan-ose, J, Idahosa,M \& Adewole-Odeshi, E. (2014) Adoption and use of information and communication technologies (ICTs) in library and information centres: Implications on teaching and learning process in Adeoye, B. F and Tomei. L. (Ed). Effect of Information Capitalism and Globalization on Teaching and Learning. Hershey, PA, IGI-Global Pp.78-87 DOI: 10.4018/978-1-4666-61622.ch006

[16] Idiegbeyan-ose, J., Owolabi, A., Segun-Adeniran, C., Aregbesola, A., Owolabi, S., \& Eyiolorunshe, T. (2018). Information Provision by Public Library to Agricultural Extension Agents in a Developing Country. Public Library https://doi.org/10.1080/01616846.2018.1555412.

[17] Yusuf, F., Owolabi, S., Aregbesola, A., Oguntayo, S., Okocha, F., \& Eyiolorunse, T. (2016). Demographics, Socio-Economic and Cognitive Skills as Barriers to Information Seeking in a Digital Library Environment. In A. Tella (Ed.), Information Seeking Behavior and Challenges in Digital Libraries (pp. 179-202). Hershey, PA: IGI Global. doi:10.4018/978-1-5225-0296-8.ch009.

[18] Nok, G. (2006). The challenges of computerizing a university library in Nigeria. The case study of Kashim Ibrahim Library, Ahmadu Bello University, Zaria. Library Philosophy and Practice. 8(2).

[19] Ossai-Ugbah, N. B. (2010). The impact of automated library services and usage on student's academic performance in Nigerian Universities. International Journal of Library and Information Science, 2(9), 169-176. 